\title{
The Role of a Temperament Intervention in Kindergarten Children's Standardized Academic Achievement
}

\author{
Ashleigh Collins ${ }^{1}$, Erin O’Connor ${ }^{2}$, Sandee McClowry ${ }^{3}$ \\ ${ }^{1}$ Relay Graduate School of Education, Director of Content, USA \\ ${ }^{2}$ New York University, Department of Teaching \& Learning, USA \\ ${ }^{3}$ New York University, Department of Applied Psychology \& Department of Teaching and Learning, USA \\ Correspondence: Ashleigh Collins, PhD, Relay Graduate School of Education, USA.
}

Received: September 18, 2016

Accepted: January 4, 2017 Online Published: January 11, 2017

doi:10.11114/jets.v5i2.2138

URL: http://dx.doi.org/10.11114/jets.v5i2.2138

\begin{abstract}
Previous research finds that children experience a range of school readiness challenges (e.g., Chartier, Walker, \& Naimark, 2010; Zill, 1999). Such challenges vary by children's gender, temperament, and participation in school-based interventions (e.g., Mullola et al., 2011; Bramlett, Scott, Rowell, 2000). However, the examination of child temperament, gender, and children's participation in school-based, temperament programming has been minimal. This study explores the role of child temperament profiles and child gender on children's standardized academic outcomes following participation in a school-based, temperament intervention. Study participants included 324 kindergarten students attending urban, low-income schools. A multivariate regression analysis explored associations among child temperament profile, gender, and academic performance. Cautious and male kindergarten intervention participants attained higher standardized mathematics and literacy scores than their non-intervention participating counterparts.
\end{abstract}

Keywords: temperament, kindergarten, urban, low-income, intervention

\section{Introduction}

A robust literature shows that school-based interventions can be promotive conduits for early child achievement (Webster-Stratton, Reid, \& Hammond, 2001; Ramey et al., 2000; Schweinhart \& Weikart, 1997). High-quality early childhood interventions can serve as an antecedent for children's later academic development (Maier, Vitiello, \& Greenfield, 2012; Duncan et al., 2007; DiPerna, Volpe, \& Elliot, 2005; Rimm-Kaufman, Pianta, \& Cox, 2000; Shonkoff $\&$ Phillips, 2000). Given the importance of early academic success, numerous interventions focus on children's early development (Furlong, McGilloway, Bywater, Hutchings, Smith, \& Donnelly, 2012; Fuchs, Fuchs, Thompson, Otaiba, Yen, McMaster, Svenson, \& Yang, 2001; Webster-Stratton \& Taylor, 2001; Domitrovich \& Greenberg, 2000). A growing body of research finds temperament-based interventions instrumental in children's social, emotional, and academic development (Collins, O'Connor, McClowry, in progress, McClowry \& Collins, 2012). Temperament-based interventions promote a goodness-of-fit between children's temperament and environment by tailoring caregiver responsiveness to meet children's socio-emotional supports needs (McClowry, 2003; Melvin, 1995).

Little research, however, exists on how the academic outcomes of temperament-based interventions may vary based on child gender and temperament. Child gender has long been associated with children's early academic skills (e.g., McWayne et al., 2012; Bramlett, Scott, \& Rowell, 2000; Silver et al., 2005; Martin, 1989, 1994). Girls tend to outperform boys on early reading and mathematics assessments (Quirk, Nylund-Gibson, \& Furlong, 2013; McCabe, Cunnington, \& Brooks-Gunn, 2004; Willingham \& Cole, 1997). Gender differences are likely to affect children's school-based intervention outcomes as well (Codding, Chan-Iannetta, George, Ferreira, \& Volpe, 2011; Kellam, Werthamer-Larsson, Dolan, Brown, Mayer, et al., 1991). Males in the control group tend to have more negative outcomes than non-intervention participating females (Conduct Problems Prevention Research Group, 2010; Domitrovich \& Greenberg, 2000; Dolan, Kellam, Brown, Werthamer-Larson, Rebok, et al., 1993), and participating males tend to have greater intervention outcomes than participating females (Cameron, Rice, Sparkman, \& Neville, 2013; Denham, Bassett, Thayer, Mincic, Sirotkin, \& et al., 2012).

Child temperament can influence the ways children approach new academic endeavors, attend to instructional content, 
collaborate with peers, and recover from academic setbacks (Zentner \& Shiner, 2012; Prior, Sanson, Smart, \& Oberklaid, 2000; Rothbart \& Bates, 1998). Children with temperaments high in negative reactivity, activity, withdrawal or low in task persistence often face difficulties with early academic skill acquisition (Denham et al., 2012; Newman et al., 1998; Schaughency \& Fagot, 1993). High negative reactivity can make the kindergarten transition particularly challenging, given the considerable change to children's daily routines (Pekrun et al., 2009; Schultz et al., 2009; Perbandt, 2007; McClowry, 2003; Gilliom et al., 2002; Carson \& Bittner, 1994). Children high in activity can create classroom disruptions and other behavioral challenges for teachers (Rudasill \& Rimm-Kaufman, 2009; Deater-Decker, et al., 2005; Li et al., 2009; Rothbart \& Jones, 1998). For highly withdrawn children, a hesitancy to engage in new experiences undermines their academic motivation and engagement (Gilman \& Anderman, 2006; Davidson et al., 2000; Furnham \& Mitchell, 1991). Children low in task persistence's difficulty attending results in prevailingly low reading and mathematical achievement (Arnold, et al., 2012; McClelland et al., 2013; Rabiner et al., 2004).

Thus, the design and outcomes of interventions may vary by child temperament (Collins, O'Connor, McClowry, in progress; Social and Character Development Research Consortium, 2010; Veenstra, Lindenberg, Oldehinkel, de Winter, \& Ormel, 2006). Preventive interventions strive to mitigate the temperamental risk of children high in activity, withdrawal, negative reactivity, and low in task persistence (Herman et al., 2011; Raver, et al., 2005, 2011; Webster-Stratton, Reid, \& Hammond, 2001). Research also suggests that children at temperamental risk may benefit more from socio-emotional interventions than their low risk peers (McCormick, O'Connor, Cappella, \& McClowry, 2015; Roorda, Koomeen, Thijs, \& Oort, 2013; Wilson, Gottfredson, \& Najaka, 2001). With a focus on creating a goodness-of-fit between child temperament and environment, temperament interventions may be uniquely positioned to influence children at risk of underachievement (Curby et al., 2011; Liew, Chen, \& Hughes, 2010; Valiente, Lemery-Chalfant, Swanson, \& Reiser, 2008; Zentner \& Bates, 2008).

With kindergarten achievement associated with children's long-term academic development, it is an especially significant period to evaluate intervention efficacy (Rouse \& Fantuzzo, 2009; Duncan et al., 2007; Konold \& Pianta, 2005; Rimm-Kaufman, Pianta, \& Cox, 2000). Nearly two-fifths of entering kindergarten students lacks the skills to acclimate to kindergarten academics and succeed in future grades (Zill, 1999). Low-income, male kindergarten children face greater academic risk. Children attending kindergarten in high poverty, urban neighborhoods face frequent stressors that can have enduring and diminishing effect on their mastery of new academic concepts (Chartier, Walker, \& Naimark, 2010; Evans \& Schamberg, 2009; Lloyd, Li, \& Hertzman, 2009). Such neighborhoods routinely expose children to chronic community violence, failing schools, residential instability, and financial difficulty (Hair, Hanson, Wolfe, \& Pollak, 2015; Bush, et al., 2011; Evans \& Schamberg, 2009; Noguera, 2008, 2003; Garbino, Dubrow, Kostelny, \& Pardo, 1992). All are factors that can increase the emotional, attentional, and social behaviors that impede children's ability to absorb new instruction and acquire positive school perceptions (Burke et al., 2011; Chartier, Walker, \& Naimark, 2010; Sharkey, 2009; Brooks-Gunn, Duncan, \& Aber, 1997).

Low-income, minority males are exposed to even greater societal risk factors than females (Noguera, 2003; Davis, 2003; Buka, Stichick, Birdthistle, \& Earls, 2001). They are the observers of more violence, bearers of lower life expectancies, recipients of more school discipline, and possessors of more stress than their female counterparts (Rudd, 2014; U.S. Department of Education Office for Civil Rights, 2014; Wood, Kaplan, \& McLoyd, 2007; Buka, Stichick, Birdthistle, \& Earls, 2001). In kindergarten, low-income, males are disproportionately at-risk for low academic achievement (Denham, Bassett, Thayer, Mincic, Sirotkin, \& Zinsser, 2012; Kohen, Oliver, \& Pierre, 2009; McWayne, Cheung, Wright, \& Hahs-Vaugh, 2004; NICHD ECCRN, 2003). Yet, research rarely addresses the role of multiple risk factors on children's participation in temperament-based interventions and early academic progress.

This study will consider the roles of child gender and temperament in urban, low-income kindergarteners' temperament-based intervention participation. The intervention, INSIGHTS into Children's Temperament, is a manualized temperament intervention that aims to enhance the socio-emotional and academic development of urban, low-income, early elementary children. INSIGHTS including teacher, parent, and child programs. Parents and teachers learn a framework for supporting children's temperamental. Children learn to a temperament lexicon and peer conflict resolution.

\section{Literature Review}

\subsection{Social and Emotional Learning Interventions}

Among the interventions supporting early child development, Social and Emotional Learning (SEL) interventions promote the development of children's social and emotional functioning (McIntosh, et al., 2012; Durlak et al., 2011; Blair \& Razza, 2007; Zins et al., 2004; Hockenberger, Goldstein, \& Haas, 1999; Velting \& Whitehurst, 1997). For children at-risk for socio-emotional difficulties, SEL interventions have proven even more efficacious (Mathewson et al., 2012; Rudasill, Gallagher, \& White, 2010). SEL interventions typically develop the attention, self-regulation, and social 
skills instrumental in high academic performance (Blair \& Diamond, 2007; Posner \& Rothbart, 2005). While SEL programs focus on the development of children's self-regulatory and social skills, they often do so at the exclusion of child temperament (Durlak et al., 2011; Blair \& Diamond, 2007; Posner \& Rothbart, 2005; Izard, 2002; Compas et al., 1991).

\subsection{Child Temperament}

Child temperament refers to the constitutional differences in reactivity and self-regulation, which affect children's emotional, cognitive, attentional, and social responses (Zentner \& Shiner, 2012). In the classroom setting, differences in child attention, activity, positive affect, and withdrawal/approach impact children's classroom engagement and academic performance (Cole, Martin, Dennis, 2004; Eisenberg, Fabes, Guthrie, \& Reiser, 2000; Derryberry \& Reed, 1996; Rothbart et al., 2000). The associations between child temperament and early academic outcomes are stronger than the association between children's cognitive aptitude and academic outcomes (Entwistle, Alexander, \& Olson, 2005).

Temperament studies consistently mention four temperament dimensions for school-age children: task persistence, activity, withdrawal, and negative reactivity (Lyons-Thomas \& McClowry, 2012; McClowry, 1995; Rothbart \& Bates, 1998; Martin, Wisenbaker, \& Huttenen, 1994; Martin, 1994). Task persistence refers to children's ability to sustain their attention on a task (Rothbart \& Bates, 2006). Children high in task persistence complete assigned tasks, meet behavioral expectations, and usually demonstrate higher academic competence (Trentacosta \& Izard, 2007; Bramlett, Scott, \& Rowell, 2000; Martin \& Holbrook, 1985).

Child activity refers to children's level of motor activity (Strelau \& Zawadzki, 2012; Rothbart \& Jones, 1998; Martin \& Holbrook, 1985). High activity is associated with learning difficulties and low academic achievement (Schaughency \& Fagot, 1993; Palisin, 1986; Martin \& Holbrook, 1985). Withdrawal refers to children's level of behavioral inhibition and reluctance to engage in new interpersonal or environmental interactions (Neal \& Edelmann, 2003; Achenbach \& Edelbrock, 1981). High withdrawal is believed to decrease children's academic motivation, participation in new learning experiences, and, in turn, diminish their attendance and grade point averages (Gilman \& Anderman, 2006; Davidson et al., 2000; Furnham \& Mitchell, 1991).

Child negative reactivity refers to children's tendency to exhibit negative responses to minor inconveniences (McClowry, 2003). High negative reactivity can inhibit children's attention, cooperative learning, academic motivation, and information recall (Pekrun et al., 2009; Schultz et al., 2009; Perbandt, 2007; Granziano, et al., 2007; Gilliom et al., 2002). Consequently, children with high negative reactivity have difficulty not only acquiring early academic skills but also are at risk for overall academic underachievement (Denham et al., 2012; Newman et al., 1998).

\subsection{Child Temperament Profiles}

While child temperament occurs on a continuum of individual dimensions, temperament profiles offfer combinations of dimensions to explore the role of temperament on achievement (Althoff, Ayer, Crehan, Rettew, Baer, \& Hudziak, 2012; Janson \& Mathiesen, 2008). Temperament profiles can be created using factor analysis to identify reoccurring temperament dimension combinations from temperament questionnaires, and, then, using those reoccurrences to develop best-fit profiles (Gartstein et al., 2012; Zalewski et al., 2011; Rettew, et al., 2010; Caspi \& Silva, 1995). Since child temperament profiles are derived from frequently occurring combinations of children's temperament, they are generalizable across temperament scales, analytical approaches, and study samples (Janson \& Mathieson, 2008).

Seminal temperament researchers Thomas, Chess, and Birch (1968) identified three temperament profiles--"easy," "difficult," and "slow-to-warm up"-in their New York Longitudinal Study. "Easy" profile children are high in approach, adaptation, and positive emotionality (Thomas \& Chess, 1977; Thomas, Chess, \& Birch, 1968). "Difficult" profile children are high in withdrawal, slow in adaptation, and high in negative emotionality (Thomas \& Chess, 1977; Thomas, Chess, \& Birch, 1968), and "Slow-to-warm up" children are high in withdrawal and slow to acclimate to new situations and social interactions (Thomas \& Chess, 1977). Subsequent temperament research reinforces Thomas and Chess (1977)'s findings that temperamentally "easy" children tend to be easily adaptive to new environments, while "difficult" and "slow to warm up" children are at-risk for maladjustment (Zalewski et al., 2011; Aksan et al., 1999; Hart et al., 1997; Robins et al., 1996; Caspi \& Silva, 1995).

McClowry (2002)'s temperament profiles combine aspects of Thomas and Chess (1977)'s "easy" and "difficult" profiles to focus on an early school-age sample. The temperament profiles include high maintenance, cautious/slow-to-warm up, industrious, and social/eager-to-try. Children with a high maintenance profile have temperaments that are high in activity and negative reactivity, and low task persistence. Cautious/slow-to-warm children are high in withdrawal. Children with an industrious profile exhibit high task persistence, low activity, and low negative reactivity. Social/eager-to-try children are low in withdrawal. Similar to Chess and Thomas' (1977) findings, high 
maintenance and cautious/slow-to-warm up child profiles are considered "challenging" temperaments. Industrious and social/eager-to-try child profiles are considered "easy" temperaments (McClowry, 2002a).

Children of "easy" profiles tend to achieve at high academic levels, while children of "challenging" profiles achieve at low academic levels (Thomas, 2003; Blair, 2002; Bramlett, Scott, \& Rowell, 2000; Guerin, et al., 2000; Martin, 1989). Researchers believe that the academic differences between "easy" and "challenging" child temperaments could be the result of any number of factors, including temperamentally-based differences in children's self-regulation, academic motivation, and teacher/child relationship quality (Koles, O'Connor, \& Collins, 2013; Walker \& Henderson, 2012; Al-Hendawi \& Reed, 2012; Rimm-Kaufman, Curby, Grimm, Nathanson, \& Brock, 2009; Rudasill \& Rimm-Kaufman, 2009; Guerin, Gottfried, Oliver, \& Thomas, 2003). Regardless, child temperament is a factor of increasing importance in children's academic success (Collins, O'Connor, McClowry, in progress; Zentner \& Shiner, 2012; Mendez, Fantuzzo, $\&$ Cicchetti, 2002; Martin, Olejnik, \& Gaddis, 1994).

\subsection{Temperament Based Interventions}

Chess and Thomas (1999) found that goodness of fit, or a match between a child's temperament and environment, promotes positive child development among all temperaments. Temperament-based interventions tailor socio-emotional supports to meet children's temperamental needs and enhance the goodness-of-fit between children and their environments (Zentner \& Bates, 2008; Bates \& Pettit, 2007; Rothbart \& Bates, 2006; McClowry, 2003; Thomas \& Chess, 1977). Goodness of fit can ease children's school transition, enhance teacher/child relationships, and protect children against academic risk factors, including those stemming from child temperament, gender, and socio-economic status (Curby et al., 2011; Liew, Chen, \& Hughes, 2009; Valiente et al., 2008; McClowry, 2003; Teerikangas et al., 1998).

\subsection{Child Temperament and Temperament-based Interventions}

Temperament-based interventions enhance a goodness of fit based on the belief that a bidirectional interaction between child temperament and children's environment influences child outcomes (Lengua \& Kovacs, 2005; Chess \& Thomas, 1999). When there is a goodness of fit between child temperament and classroom environment, children can achieve positive school outcomes, including high academic achievement (Collins \& O'Connor, 2016; McClowry, Rodriguez, \& Koslowitz, 2008; O'Connor \& McCartney, 2007; Hamre \& Pianta, 2001; McClowry, 2003; Chess \& Thomas, 1999; Melvin, 1995). Children of differing temperaments are likely to experience and attain different outcomes from classrooms and interventions, based on whether such circumstances produce a goodness- or poorness- of fit (McClowry \& Collins, 2012; Zentner \& Shiner, 2012; O’Connor, Cappella, Rodriguez, \& McClowry, 2010). For example, a hospital management organization (HMO)-based intervention provided preschool-age parents with temperament-based, parenting literature (Cameron, Rice, Sparkman, \& Neville, 2013). Among the children whose parents participated in the intervention, the greatest behavioral change occurred in children of "challenging" temperaments. The temperamentally challenging participants had fewer behavior-related, pediatric visits.

Similarly, past research on the INSIGHTS into Children's Temperament, the program on which this study is based, finds "challenging," high maintenance children receive quicker decreases in off-task and disruptive behaviors compared to children of social, cautious, and industrious temperament profiles (McCormick, O'Connor, Cappella, \& McClowry, 2015; McClowry, Rodriguez, Tamis-LeMonda, Spellman, Carlson, \& Snow, 2013; O'Connor, Rodriguez, Cappella, Morris, \& McClowry, 2013). Cautious children also achieved speedier academic development in math and critical thinking than social children (O’Connor, Cappella, McCormick, \& McClowry, 2014).

\subsection{Temperament-based Interventions and Child Gender}

In addition to child temperament, gender may also affect children's intervention outcomes. Child gender has already proved to moderate academic outcomes (Lawson \& Ruff, 2004; Kochanska et al., 1996). Demonstrated gender differences exist in children's teacher relationship quality (Stipek \& Miles, 2008; Rudasill \& Rimm-Kaufman, 2008; Pianta, et al., 2002), teachers' expectations of students (Denham, Bassett, Mincic, Kalb, Way, Wyatt, \& Segal, 2012; Wood, Kaplan, \& McLoyd, 2007; McClowry, 2002; LaFreniere \& Dumas, 1996), and overall academic achievement (Quirk, Nylund-Gibson, \& Furlong, 2013; McCabe, Cunnington, \& Brooks-Gunn, 2004; Willingham \& Cole, 1997). Teacher-child relationships among female students are closer and less conflictual than male students (Baker, 2006; Hamre \& Pianta, 2001; Birch \& Ladd, 1997). Teachers perceive male students as having more behavior problems and less school readiness skills than female students (McWayne, Cheung, Wright, \& Hahs-Vaughn, 2012; Kohen, Oliver, \& Pierre, 2009; LaFreniere \& Dumas, 1996). Moreover, females with positive teacher/child relationships attain greater school outcomes than males experiencing the same relationship quality (Baker, 2006).

It remains unclear whether temperamentally different outcomes occur as a function of child gender. Teachers tend to view male students as not only possessing the components associated with "challenging" temperaments (high negative 
reactivity and activity), but also as possessing low academic competence (Denham, Bassett, Mincic, Kalb, Way, Wyatt, \& Segal, 2012; Valiente, Lemery-Chalfant, \& Swanson, 2010; Prior, Sanson, Smart, \& Oberklaid, 2000; LaFreniere \& Dumas, 1996; McClowry, Giangrande, Tommasini, Clinton, Foreman, \& Ferketich, 1994). Conversely, teachers view female students as displaying the components of "easy" temperaments (high in task persistence and low activity) and high academic competence (Valiente, Swanson, \& Eisenberg, 2012; Deater-Deckard, Mullineaux, Petrill, Thompson, \& DeThorne, 2009; McClowry, 2002; LaFreniere \& Dumas, 1996; Fergusson, Lloyd, \& Horwood, 1991).

\subsection{Current Study}

This study will investigate associations between children's temperament, gender, temperament intervention participation, and academic development. Additionally, this study will focus on a program underrepresented in intervention literature, temperament-based programming, and a population especially susceptible to low achievement — urban, kindergarten students attending high poverty schools. Identifying the processes that may underlie child temperament and academic development can inform early school supports and potentially protect against early low achievement. The following research questions will be tested:

1) What are the effects of INSIGHTS into Children's Temperament on the academic development of low-income, urban kindergarten children?

2) What is the role of gender and temperament typology in children's academic development?

\section{Methods}

\subsection{Participants}

Analyses were conducted on a sample of 324 students from twenty-two underserved, urban elementary schools. Students attended 120 classrooms and ranged in age from four to seven $(M=5.55$ years). Fifty-two percent of the students were male. The majority of the students were African-American (72\%) or Latino (19\%), and they qualified for free or reduced lunch (87\%). Participating teachers were predominately female (94.2\%) and African-American (56.4\% African-American). A sizeable amount of teachers were also White (24.3\%), Latino (11.9\%), and of mixed or other races $(7 \%)$. After baseline data was collected, participating schools were randomly assigned to the INSIGHTS into Children's Temperament program or an attention control, reading program.

\subsection{Procedure}

Participant teachers and kindergarten families were recruited via letters, fliers, telephone calls, and brief parent meeting presentations. Once a parent provided consent, their child was asked for their assent. Parents completed the School-Aged Temperament Inventory (McClowry, 1995), and trained observers administered the Woodcock-Johnson Applied Problems and Woodcock-Johnson Letter-Word subtests to determine children's reading and math skills. Data was collected across five time points: in early kindergarten, after a 10 -week intervention, at the beginning of $1^{\text {st }}$ grade, after the completion of the 10-week intervention, and at the end of $1^{\text {st }}$ grade. This study was conducted with three cohorts and focuses on the pre- and post- intervention data for kindergarteners across three academic years (2009-2012).

\subsection{Program Description}

Data for the current study was from the Prevent III INSIGHTS into Children's Temperament (INSIGHTS) study (McClowry, O'Connor, \& Cappella, 2008-20012). INSIGHTS is a temperament-based, manualized, Tier 1 preventive intervention that includes teacher, parent, and child components. Teachers and parents were taught how to foster a goodness-of-fit between child temperament and child environment by using the three R's-Recognize, Reframe, and Respond (McClowry, 2002a, 2002b). Participants learn to recognize child behavior as offshoots of unique temperament types (McClowry et al., 2009); reframe their perceptions of temperament by acknowledging that all profiles have strengths and challenges; and respond to child temperament in ways that facilitate a goodness of fit (McClowry, 2009). The adult workshops were delivered in two-hour, weekly-facilitated sessions, over a 10 -week period. Sessions relied on a structured curriculum that included didactic content, videotaped vignettes, session handouts, and group discussion.

During the same 10-week period, kindergarten children participated in weekly, 45-minute classroom sessions. In the children's sessions, a facilitator used vignettes and drama therapy techniques to teach children conflict resolution and that temperament may lead to situational ease or challenge. Workbook sheets and vocabulary flash cards were also used to extend children's understanding of temperament and problem solving.

Children were introduced to four puppets, which each represented a temperament profile - Coretta the Cautious, Fredrico the Friendly, Gregory the Grumpy, and Hilary the Hardworker (McClowry, 2002). Coretta the Cautious embodies the cautious/slow to warm up temperament profile. She is high in withdrawal and reticent with new people and experiences. Fredrico the Friendly reflects the social/eager to try temperament profile. He is high in approach and enthusiastically embraces new experiences and people. Gregory the Grumpy possesses the high maintenance 
temperament profile. He is highly active, highly reactive to disappointments, and easily distracted during task completion. Hilary the Hardworker represents the industrious temperament profile. She approaches her tasks with conscientiousness, her movements with restraint, and her disappointments with a positive, resiliency.

In schools assigned to the attention control, children participated in a supplementary reading program for ten weeks after school. They received a comparable number of adult interactions as students participating in INSIGHTS to control for any child outcomes resulting from ten, consecutive weeks of additional adult interactions. Teachers read a different book weekly and children were asked to discuss and draw about the story. At the close of the ten weeks, the post-intervention questionnaires were redistributed.

\section{Measures}

School-Age Temperament Inventory. Child temperament was assessed using the School-Age Temperament Inventory (SATI; McClowry, 2002). The SATI is a 38-item, parent-reported, five-point Likert-response scale (where $1=$ never, $3=$ sometimes, and $5=$ always). Using a nationally diverse sample of 883 parents, the SATI was standardized and identifies students' levels of withdrawal, task persistence, negative reactivity, and activity. The Cronbach's alphas for the SATI in this study are included below. Cronbach's Alphas for the School-Age Temperament Inventory

\begin{tabular}{ll}
\hline Activity & $\alpha=0.77$ \\
Negative Reactivity & $\alpha=0.87$ \\
Task Persistence & $\alpha=0.70$ \\
Withdrawal & $\alpha=0.81$ \\
\hline
\end{tabular}

Woodcock-Johnson III Tests: The Woodcock-Johnson Applied Problems and Woodcock-Johnson Letter-Word subtests were used to assess children's math and reading achievement, respectively (Woodcock, McGrew, \& Mather, 2001). The Applied Problems subtest measures children's quantitative reasoning, math knowledge, and math achievement through 39 items (Wendling, Schrank, \& Schmitt, 2007). The Applied Problems subtest has a reliability of 0.93 (SE = 4.08). The Letter-Word Identification subtest measures children's reading decoding through 76 items. The Letter-Word Identification subtest has a reliability of $0.94(\mathrm{SE}=3.81)$.

\section{Analysis}

The role of INSIGHTS, a school-based temperament intervention, in promoting kindergarteners' academic development will be considered in a simple linear regression analysis. Child temperament profiles were created by, first, determining the level of intensity that children exhibited each of the four temperament dimensions (i.e., task persistence, negative reactivity, activity, and withdrawal). Low intensity levels occurred when temperament dimension values fell below the mean. Moderate intensity occurred for temperament dimensions within the mean, and high intensity occurred for dimensions above the mean. The industrious child profile was high in task persistence, low in activity, and low in negative reactivity. The high maintenance child profile was low in task persistence, high in activity, and high in negative reactivity. The social/eager-to-try profile was low in withdrawal, while the cautious/slow-to-warm up profile was high in withdrawal. Over eighty-nine percent $(\mathrm{M}=89.6 \%)$ of the study sample $(\mathrm{N}=275)$ qualified as one of the four temperament profiles. The greatest number of children qualified as either the social/eager-to-try profile $(\mathrm{M}=39 \%)$ or the cautious/slow-to-warm up profile $(\mathrm{M}=30 \%)$. Thirteen percent of the study population qualified as an industrious profile, and nearly eight percent qualified as a high maintenance profile $(\mathrm{M}=7.6 \%)$.

A correlation analysis of the temperament profile variables was conducted (Table 1). It revealed that the social/eager-to-try profile was significantly correlated to the high maintenance $(r=-0.119, p=0.049)$ and cautious/slow-to-warm up $(r=-0.53, p<0.001)$ profiles. Given the high correlation, the social/eager-to-try profile was omitted from the analyses. As a result, all temperament profile findings were conducted in relation to the excluded social/eager-to-try profile.

Table 1. Pearson's Product Moment Correlations for Child Temperament Profiles

\begin{tabular}{|c|c|c|c|c|}
\hline & \multicolumn{4}{|c|}{ Temperament Profiles } \\
\hline & High Maintenance & Cautious & Industrious & Social \\
\hline High Maintenance & 1 & 0.079 & $-0.113 \dagger$ & $-.119 *$ \\
\hline Cautious & 0.079 & 1 & $-.120 *$ & $-.529 * *$ \\
\hline Industrious & $-0.113 \dagger$ & $-.120 *$ & 1 & $-0.098 \dagger$ \\
\hline Social & $-.119 *$ & $-.529 * *$ & $-0.098 \dagger$ & 1 \\
\hline
\end{tabular}

A correlation matrix was, then, created to examine associations among the children's three remaining temperament profiles (high maintenance, cautious, and industrious), demographics, and temperament-based program participation to check for potential multicollinearity (See Table 2). 
Table 2. Pearson's Product Moment Correlations for Child Demographics

\begin{tabular}{lllllll}
\hline & Controls & & \multicolumn{3}{c}{ Child Temperament } \\
& Child Male & $\begin{array}{l}\text { Parent } \\
\text { Education }\end{array}$ & $\begin{array}{l}\text { Program } \\
\text { Participation }\end{array}$ & $\begin{array}{l}\text { High } \\
\text { Maintenance }\end{array}$ & Cautious & Industrious \\
\hline Child Male & 1.00 & 0.03 & 0.00 & $0.09 \dagger$ & -0.02 & -0.06 \\
Parent Education & 0.03 & 1.00 & $-0.19 * *$ & 0.03 & $-0.18^{* *}$ & 0.04 \\
Program Participation & 0.00 & $-0.19 * *$ & 1.00 & -0.05 & -0.06 & $0.11 \dagger$ \\
High Maintenance & $0.09 \dagger$ & 0.03 & -0.05 & 1.00 & 0.08 & $-0.11 \dagger$ \\
Cautious & -0.02 & $-0.18^{* *}$ & -0.06 & 0.08 & 1.00 & $-0.12^{*}$ \\
Industrious & -0.06 & 0.04 & $0.11 \dagger$ & $-0.11 \dagger$ & $-0.12^{*}$ & 1.00 \\
\hline
\end{tabular}

Note. $\dagger=\mathrm{p} \leq .10, *=\mathrm{p} \leq .05, * *=\mathrm{p} \leq .01$

Child temperament, gender, and parental education were entered as control variables in the regression model predicting children's literacy and mathematical skills. Child gender (where $0=$ female and $1=$ male) and child intervention participation (where $0=$ not a participant in the intervention and $1=$ participant in the intervention) were both dummy coded. Parent education was coded using the following four categories: $0=$ did not complete high school, $1=$ completed high school, 2 = completed some college, and $4=$ completed college.

Child gender, temperament, and program participation were entered into the regression model to predict children's academic skills, along with three, two-way interaction terms (children's program participation X children's temperament profiles) to determine whether intervention outcomes varied as a function of child temperament. An additional two-way interaction term (children's program participation X children's gender) was added to examine whether intervention outcomes varied as a function of child gender. Finally, three, three-way interaction terms (children's program participation X child temperament X child gender) were added to explore whether intervention outcomes varied as a result of both children's gender and temperament. Significance was tested.

Missing Data. Common to school-based research (Puma, et al., 2009), there was missing student data due to random student absences, family travel, transiency, or occasional conflicts between the school calendar and research collection. Since the data was missing randomly, listwise deletion was used. Following listwise deletion, the final sample size was 275.

\section{Results}

What are the effects of INSIGHTS into Children's Temperament on the academic development of low-income, urban kindergarten children?

There was a statistically significant effect of children's participation in the INSIGHTS into Children's Temperament program on children's literacy performance (See Table 3). Between entering kindergarten (baseline) and mid-fall of kindergarten, children's participation in the temperament-based program was inversely related to their Woodcock-Johnson Letter Word $(b=-2.10, \mathrm{SE}=0.62, \mathrm{p} \leq 0.01)$. The inverse relationship between children's program participation and Woodcock-Johnson Applied Problems scores was not statistically significant $(b=-0.37, \mathrm{SE}=0.51, \mathrm{p}=$ 0.47).

Table 3. Child gender, temperament, and program participation predicting Woodcock Johnson scores

\begin{tabular}{lllll}
\hline & Letter Word & \multicolumn{3}{c}{ Applied Problems } \\
& $\mathrm{b}$ & $\mathrm{b}$ & $\mathrm{b}$ & \multicolumn{1}{c}{ SE } \\
\hline Constant & $8.21^{* *}$ & 1.87 & $11.95^{* *}$ & 0.53 \\
Child Male & -0.85 & 0.61 & -1.14 & 0.10 \\
Parent Education & 0.13 & 0.12 & 0.05 & 0.10 \\
Program participation & $-2.10^{* *}$ & 0.62 & -0.37 & 0.51 \\
Woodcock-Johnson (T1) & $0.78^{* *}$ & 0.04 & $0.31^{* *}$ & 0.03 \\
Cautious & 0.09 & 0.67 & -0.61 & 0.55 \\
High Maintenance & $-2.58^{*}$ & 1.19 & -1.06 & 0.97 \\
Industrious & 0.00 & 0.91 & -0.66 & 0.75 \\
\hline
\end{tabular}

Note. $\dagger=\mathrm{p} \leq .10, *=\mathrm{p} \leq .05, * *=\mathrm{p} \leq .01$

What is the role of gender and temperament typology in children's academic development?

Gender and child temperament proved to influence children's intervention outcomes and academic development. Gender had a statistically significant moderation effect on children's INSIGHTS program participation and Woodcock-Johnson Applied Problems $(b=-1.55, \mathrm{SE}=0.93, \mathrm{p} \leq 0.10)$ scores. Male program participants scored lower on the Woodcock-Johnson Applied Problems assessment than females in the intervention. There was no gender moderating effect for child program participation and Woodcock-Johnson Letter Word scores.

While child temperament did not moderate the relationship between children's program participation and academic performance, high maintenance children scored significantly lower on the Woodcock-Johnson Letter Word assessment 
$(\mathrm{b}=-2.58, \mathrm{SE}=1.19, \mathrm{p} \leq 0.05)$ compared to children of other temperament profiles. There were no temperamental effects on children's Woodcock-Johnson Applied Problems performance.

The interaction of child gender, temperament, and program participation did have a statistically significant moderation effect on children's academic performance. For literacy performance, industrious males in the intervention scored higher on the Woodcock-Johnson Letter-Word assessment than their non-participating counterparts $(b=-3.79, \mathrm{SE}=$ $2.02, \mathrm{p} \leq 0.10)$. For math performance, cautious males in the intervention scored higher on the Woodcock-Johnson Applied Problems than non-participating cautious males $(b=-2.43, \mathrm{SE}=1.11, \mathrm{p} \leq 0.05)$. There were no statistically significant effects for any of the other three-way interaction terms.

\section{Discussion}

This study found that child gender, temperament, and participation in a temperament-based program influenced kindergarten children's standardized literacy and math scores. It also showed that study main effects do not always offer a complete depiction of study outcomes. The study main effects found children's program participation negatively influenced children's literacy scores. However, upon closer examination, the interaction effects reveal higher literacy and mathematics scores for subsets of program participants. Such population-specific observations are of particular importance given that it is child subsets (including kindergarteners, low-income children, challenging child temperaments, and boys) who are at risk for academic and intervention underachievement (McWayne, Cheung, Wright, \& Hahs-Vaughn, 2012).

Among the subsets of children who received academic gains following the study's program participation were children at risk for low achievement-including cautious children and male children. Male kindergartners not only have disproportionately lower academic readiness skills than females (Denham et al., 2012; McWayne et al., 2004; Wills, et al., 1996), but are also perceived by teachers to have lower academic ability (Kohen, Oliver, \& Pierre, 2009; Baker, 2006; Hamre \& Pianta, 2001). Yet, male children in this study attained higher literacy scores when they both participated in the temperament-based program and possessed an industrious temperament profile.

Additionally, cautious children are predisposed toward low academic achievement (Vilijaranta, Aunola, Mullola, Virkkala, Hirvonen, et al, 2015; Rudasill \& Rimm-Kaufman, 2009; Rydell, Bohlin, \& Thorell, 2005). Their reserve minimizes interactions with teachers and peers, circumventing two proven academic supports (Collins \& O'Connor, 2016; Koles, O'Connor, \& Collins, 2013). However, cautious boys in this study, who participated in the program, attained higher math scores than program-participating girls.

It is possible that the temperament program's adult workshops increased teacher awareness and responsiveness to all children, including the typically overlooked cautious and male children (Rudasill \& Rimm-Kaufman, 2009). Close teacher/child relationships and teacher responsiveness have proven especially beneficial to the academic development of cautious children (Collins \& O'Connor, 2016; Vilijaranta, Aunola, Mullola, Virkkala, Hirvonen, et al, 2015; Koles, O'Connor, \& Collins, 2013). Cautious and male children also seem to respond especially well to temperament-based interventions (Collins, O'Connor, \& McClowry, In progress; Vilijaranta, Aunola, Mullola, Virkkala, Hirvonen, et al, 2015; O’Connor, Cappella, McCormick, \& McClowry, 2014; Kochanska et al., 1996).

Additionally, this study reinforced previous research that male students and students with challenging temperaments score lower on kindergarten academic measures (Denham et al., 2012; Stright, Gallagher, \& Kelly, 2008; NICHD ECCRN, 2003; Bramlett, Scott, \& Rowell, 2000). Male program participants scored lower on the standardized mathematics assessment compared to their female peers, and children with the challenging, high maintenance temperament scored lower on the standardized literacy assessment than other temperament profiles. The kindergarten transition as well as children's acclimation to intervention participation may have compounded the amount of change high maintenance children faced. The increased dissonance between children's temperament and new environmental may have resulted in high maintenance children's low literacy achievement.

\section{Limitations}

This study focuses on children's program participation and academic achievement at the initial stages of school adjustment, the beginning through the late fall of children's kindergarten year. While the stage is critical to children's enduring attitudes toward school, student-teacher relationship quality, and academic trajectory (Baker, 2006; Silver et al., 2005; Pianta \& Stuhlman, 2004; Hamre \& Pianta, 2001; Alexander, Entwisle, Blyth, \& McAdoo, 2012), it is only a snippet of children's overall kindergarten experience. Research that includes multiple time points across the kindergarten year could contribute to the temperament intervention literature.

Second, this study focuses on the roles of child temperament and gender on the relationship between children's program participation and early achievement. Study program participation may have changed the quality of teacher-child relationships, which in turn, affected the relationship between child characteristics (such as temperament and gender) 
and academic outcomes. Future research would do well to investigate the potential role of additional factors.

Third, temperament intervention outcomes were compared to an attentional, control program. Despite intending for the control to offer comparable amounts of teacher-child interactions as the intervention group, it is possible that the program also offered an unintentional, literacy intervention. The control's use of teaching professionals, quality literature, and related comprehension activities may have enhanced children's literacy performance.

Fourth, and finally, once missing data was considered, the sample consisted of 275 children. Despite, a fairly small sample, the study findings offer a noteworthy contribution to temperament intervention research, particularly for kindergarten children, attending schools in urban, low-income neighborhoods. Still, future research on this topic and demographic would benefit from a larger sample size.

\section{Implications for Practice}

It is customary for intervention research to rely on study main effects to determine program efficacy (Blasé, Fixsen, Sims, \& Ward, 2014). While the main effects in intervention research offer a valuable perspective on program outcomes, an exclusive focus on main effects can overlook the nuances of subgroup participant experiences (Kam, Greenberg, \& Walls, 2003; Ialongo, Werthamer, Kellam, Brown, Wang, \& Lin, 11999). In this study, the main effects found intervention participation to negatively influence kindergarteners' literacy scores. Taken at face value, this study's temperament based intervention could have been easily dismissed as inefficacious. However, further investigation into the study's interaction effects revealed that the main effects belied the intervention's positive influence on two academically at-risk groups, kindergarten males and cautious child temperaments. As a result, it is critical to consider both main and interaction effects in order to establish a comprehensive understanding of intervention implementation and outcomes.

This study's temperament-based intervention proved especially beneficial to child subgroups at risk of low academic performance. Industrious and cautious kindergarten males who participated in the intervention attained higher literacy and math scores, respectively, than their non-participating counterparts. Their academic success highlights the utility of temperament-based programming for children at risk for academic underachievement. While the specific intervention mechanisms instrumental in children's academic performance could stand further study, two components of temperament-based intervention present in this study may offer a helpful starting point: (1) establishing "goodness of fit," and (2) reframing child behavior. The "goodness of fit" framework requires examination of the interactive relationships between children's individual characteristics, classroom climate, and intervention participation. Reframing child temperament recognizes that all temperament profiles have strengths and areas of challenge. Building teacher program participants' skill in reframing child behavior may influence teacher perception, teacher-child relationship quality, and children's academic outcomes.

Reframing child behavior is a "best practice" that teachers and intervention practitioners can adopt in their interactions with children to ease a common site of practitioner stress and turnover - classroom behavior management (Klassen \& Chiu, 2010; Jennings \& Greenberg, 2009). In reframing children's behavior, teachers and intervention facilitators expand their locus of control to include opportunities to facilitate a goodness of fit, rather than viewing challenging child behavior as a challenge to their authority. This is of particular importance given the simultaneous occurrence of negative teacher perception of "challenging" child temperaments and male students alongside both student groups' poor teacher-child relationships and low academic achievement (Collins \& O'Connor, 2016; Stipek \& Miles, 2008; Rudasill \& Rimm-Kaufman, 2008; Perbandt, 2007; Wood, Kaplan, \& McLoyd, 2007; Schaughency \& Fagot, 1993). With child behavior management negatively effecting teacher stress and retention (Klassen \& Chiu, 2010; Jennings \& Greenberg, 2009), the skill of reframing child behavior may also minimize teacher stress, retain teachers, and facilitate positive teacher-child relationships.

Finally, consistent with previous research (Dissertation 1; Stright, Gallagher, \& Kelly, 2008; Coplan, Gavinski-Molina, Lagacé-Séguin, \& Wichmann, 2001), high maintenance, cautious, and male children achieved lower academic scores than children of other temperaments and female students. Consequently, intervention efficacy must be evaluated with an understanding that program components affect children differently (Durlak et al., 2011; Ramey \& Ramey, 1999). To this end, interventions as well as school-, district-, and nation- wide education policy efforts must consider the gender, temperament, and context of participating children (Durlak et al., 2011; Domitrovich, Bradshaw, Poduska, Hoagwood, Buckley, et al., 2008).

\section{References}

Aksan, N., Goldsmith, H., Smider, N., Essex, M., Clark, R., Hyde, J., Klein, M., \& Vandell, D. (1999). Deviation and prediction of temperamental types among preschoolers. Developmental Psychology, 35(4), 958-971. https://doi.org/10.1037/0012-1649.35.4.958 
Al-Hendawi, M., \& Reed, E. (2012). Educational outcomes for children at-risk: The influence of individual differences in children's temperaments. International Journal of Special Education, 27(2), 64-74.

Althoff, R., Ayer, L., Crehan, E., Rettew, D., Baer, J., \& Hudziak, J. (2012). Temperamental profiles of dysregulated children. Child Psychiatry and Human Development, 43, 511-522. https://doi.org/10.1007/s10578-012-0280-7

August, G., Lee, S., Bloomquist, M., Realmuto, G., \& Hektner, J. (2004). Maintenance effects of an evidence-based prevention innovation for aggressive children living in culturally diverse urban neighborhoods: The early risers effectiveness study. Journal of Emotional and Behavioral Disorders, 12(4), 194-205. https://doi.org/10.1177/10634266040120040101

Baker, J. (2006). Contributions of teacher-child relationships to positive school adjustment during elementary school. Journal of School Psychology, 44, 211-229. https://doi.org/10.1016/j.jsp.2006.02.002

Bates, J., \& Pettit, G. (2007). Temperament, parenting, and socialization. In J. Grusec \& P. Hastings (Eds.), Handbook of socialization (pp. 153-177). New York, NY: Guilford.

Belsky, J., \& MacKinnon, C. (1994): Transition to school: Developmental trajectories and school experiences, Early Education \& Development, 5(2), 106-119. https://doi.org/10.1207/s15566935eed0502_3

Benner, A., \& Graham, S. (2009). The transition to high school as a developmental process among multiethnic urban youth. Child Development, 80, 356-376. https://doi.org/10.1111/j.1467-8624.2009.01265.x

Bennett, R., Gottesman, R., Rock, D., \& Cerulio, F. (1993). Influence of behavior perceptions and gender on teachers' judgments of students' academic skill. Journal of Educational Psychology, 85(2), 347-356. https://doi.org/10.1037/0022-0663.85.2.347

Blair, C. (2002). School readiness: Integrating cognition and emotion in a neurobiological conceptualization of children's functioning at school entry. American Psychologist, 57(2), 111-127. https://doi.org/10.1037/0003-066X.57.2.111

Blair, C., \& Diamond, A. Biological processes in prevention and intervention: The promotion of self-regulation as a means of preventing school failure. Developmental Psychopathology, 20(3), 899-911. https://doi.org/10.1017/s0954579408000436

Blasé, K., \& Fixsen, D. (1981). Structure of child care education: Issues and implications for educators and practitioners. Child Care Quarterly Special Issue: Emerging Issues in Child and Youth Care Educations, 10, 210-225. https://doi.org/10.1007/BF01113410

Blasé, K., Fixsen, D., Sims, B., \& Ward, C. (2014). Implementation science: Changing hearts, minds, behavior, and systems to improve educational outcomes. Oakland, CA: The Wing Institute.

Bossaert, G., Doumen, S., Buyse, E., \& Verschueren, K. (2011). Predicting children's academic achievement after the transition to first grade: A two-year longitudinal study. Journal of Applied Developmental Psychology, 32, 47-57. https://doi.org/10.1016/j.appdev.2010.12.002

Bowman, B. (1999). Kindergarten practices for children from low income homes. In R. Pianta \& M. Cox. (Eds.). The transition to kindergarten (pp. 281-301). Baltimore, MD: Paul H. Brookes.

Bramlett, R., Scott, P., \& Rowell, R. (2000). A comparison of temperament and social skills in predicting academic performance in first graders. Special Services in the Schools, 16(1-2), 147-158. https://doi.org/10.1300/J008v16n01_10

Bronfenbrenner, U. (1970). Two worlds of childhood: U.S. and U.S.S.R. New York: Sage.

Brooks-Gunn, J., Duncan, G., \& Aber, J. (Eds.). (1997). Neighborhood poverty: Vol. 1. Context and consequences for children, 2. Policy implications in studying neighborhoods. New York, NY: Russell Sage Foundation.

Brunner, M., Krauss, S., \& Kunter, M. (2008). Gender differences in mathematics: Does the story need to be rewritten? Intelligence, 36(5), 403-421. https://doi.org/10.1016/j.intell.2007.11.002

Buka, S., Stichick, T., Birdthistle, I., \& Earls, F. (2001). Youth exposure to violence: Prevalence, risks, and consequences. American Journal of Orthopsychiatry, 71(3), 298-310. https://doi.org/10.1037/0002-9432.71.3.298

Burke, N., Hellman, J., Scott, B., Weems, C., \& Carrion, V. (2011). The impact of adverse childhood experiences on an urban pediatric population. Child Abuse and Neglect, 35(6), 408-413. https://doi.org/10.1016/j.chiabu.2011.02.006

Bush, N., Obradović, J., Adler, N., \& Boyce, W. (2011). Kindergarten stressors and cumulative adrenocortical activation: The "first straws" of allostatic load? Developmental Psychopathology, 23(4), 1089-1106. https://doi.org/10.1017/S0954579411000514 
Byrd-Blake, M., Afolayan, M., Hunt, J., Fabunmi, M., Pryor, B., \& Leander, R. (2010). Morale of teachers in high poverty schools: A post-NCLB mixed methods analysis. Education and Urban Society, 42(4), 450-472. https://doi.org/10.1177/0013124510362340

Bywater, T., \& Sharples, J. (2012). Effective evidence-based interventions for emotional well-being: Lessons for policy and practice. Research Papers in Education, 27(4), 389-408. https://doi.org/10.1080/02671522.2012.690242

Cameron, J., Rice, D., Sparkman, G., \& Neville, H. (2013). Childhood temperament-based anticipatory guidance in an HMO setting: A longitudinal study. Journal of Community Psychology, 41(2), 236-248. https://doi.org/10.1002/jcop.21526

Carson, D., \& Bittner, M. (1994). Temperament and the school-aged children's coping abilities and responses to stress. The Journal of Genetic Psychology: Research and Theory on Human Development, 155(3), 289-302.

Caspi, A., \& Silva, P. (1995). Temperamental qualities at age three predict personality traits in young adulthood: Longitudinal evidence from a birth cohort. Child Development, 66, 486-498. https://doi.org/10.2307/1131592

Caspi, A., Henry, B., McGree, R., Moffitt, T., \& Silva, P. (1995). Temperamental origins of child and adolescent behavior problems: From age three to age fifteen. Child Development, 66, 55-68. https://doi.org/10.2307/1131190

Chartier, M., Walker, J., \& Naimark, B. (2010). Separate and cumulative effects of adverse childhood experiences in predicting adult health and health care utilization. Child Abuse Neglect, 34(6), 454-464. https://doi.org/10.1016/j.chiabu.2009.09.020

Chess, S., \& Thomas, A. (1986). Temperament in clinical practice. New York, NY: Guilford Press.

Chess, S., \& Thomas, A. (1999). Goodness of fit: Clinical applications for infancy through adult life. Philadelphia, PA: Bruner/Mazel.

Codding, R., Chan-Iannetta, L., George, S., Ferreira, K., \& Volpe, R. (2011). Early number skills: Examining the effects of class-wide interventions on kindergarten performance. School Psychology Quarterly, 26(1), 85-96. https://doi.org/10.1037/a0022661

Cole, P., Martin, S., \& Dennis, T. (2004). Emotion regulation as a scientific construct: Methodological challenges and directions for child development research. Child Development, 75(2), 317-333. https://doi.org/10.1111/j.1467-8624.2004.00673.x

Collaborative for Academic, Social, and Emotional Learning. (2005). Safe and sound: An educational leader's guide to evidence-based social and emotional learning (SEL) programs, Illinois edition. Chicago, IL: Collaborative for Academic, Social, and Emotional Learning.

Collins, A., \& O’Connor, E. (2016). Teacher-child relationships and child Temperament in kindergarten achievement. Journal of Educational and Developmental Psychology, 6(1), 173-195. https://doi.org/10.5539/jedp.v6n1p173

Collins, A., O'Connor, E., \& McClowry, S. (In Progress). Child temperament and early academic development. EC Psychology and Psychiatry.

Collins, L., Murphy, S., \& Bierman, K. (2004). A conceptual framework for adaptive preventive interventions. Prevention Science, 5(3), 185-196. https://doi.org/10.1023/B:PREV.0000037641.26017.00

Conduct Problems Prevention Research Group (2010). The effects of multiyear universal social-emotional learning program: The role of student and school characteristics. Journal of Consulting and Clinical Psychology, 78(2), 156-168. https://doi.org/10.1037/a0018607

Coplan, R., Barber, A., \& Lagace-Seguin, D. (1999). The role of child temperament as a predictor of early literacy and numeracy skills in preschoolers. Early Childhood Research Quarterly, 14, 537-553. https://doi.org/10.1016/S0885-2006(99)00025-3

Coplan, R., Gavinski-Molina, M., Lagacé-Séguin, D., \& Wichmann, C. (2001). When girls versus boys play alone: Nonsocial play and adjustment in kindergarten. Developmental Psychology, 37(4), 464-474. https://doi.org/10.1037/0012-1649.37.4.464

Costa, P., Terracciano, A., McCrae, R. (2001). Gender differences in personality traits across cultures: Robust and surprising findings. Journal of Personality and Social Psychology, 81, 322-331. https://doi.org/10.1037/0022-3514.81.2.322

Crosnoe, R., Morrison, F., Burchinal, M, Pianta, R., Keating, D., Friedman, S., \& Clarke-Stewart, K. (2010). Instruction, teacher-student relations, and math achievement trajectories in elementary school. Journal of Education Psychology, 102(2), 407-417. https://doi.org/10.1037/a0017762 
Curby, T., Rudasill, K., Edwards, T., \& Perez-Edgar, K. (2011). The role of classroom quality in ameliorating the academic and social risks associated with difficult temperament. School Psychology Quarterly, 26(2), 175-188. https://doi.org/10.1037/a0023042

Davis, J. (2003). Early schooling and academic achievement of African American males. Urban Education, 38(5), 515-537. https://doi.org/10.1177/0042085903256220

Dearing, E., McCartney, K., Weiss, H., Kreider, H., \& Simpkins, S. (2004). The promotive effects of family educational involvement for low-income children's literacy. Journal of School Psychology, 42(6), 445-460. https://doi.org/10.1016/j.jsp.2004.07.002

Deater-Deckard, K., Beekman, C., Wang, Z., Kim, J., Petrill, S., Thompson, L., \& DeThorne, L. (2010). Approach/positive anticipation, frustration/anger, and overt aggression in childhood. Journal of Personality, 78(3), 991-1009. https://doi.org/10.1111/j.1467-6494.2010.00640.x

Deater-Deckard, K., Dodge, K., \& Sorbring, E. Cultural differences in the effects of physical punishment. In M. Tienda, M. and M. Rutter (Eds.). Ethnicity and causal mechanism (pp. 204-226). Cambridge: Cambridge University Press. https://doi.org/10.1017/cbo9781139140348.010

Deater-Deckard, K., Mullineaux, P., Petrill, S., \& Thompson, L. (2009). Effortful control, surgency, and reading skills in middle childhood. Reading and Writing, 22(1), 107-116. https://doi.org/10.1007/s11145-007-9111-9

Denham, S., Bassett, H., Thayer, S., Mincic, M., Sirotkin, Y., \& Zinsser, K. (2012). Observing preschoolers' social-emotional behavior: Structure, foundations, and prediction of early school success. The Journal of Genetic Psychology: Research and Theory on Human Development, 173(3), 246-278. https://doi.org/10.1080/00221325.2011.597457

Denton, K., \& West, J. (2002). Children's reading and mathematics achievement in kindergarten and first grade (NCES 2002-125). U.S. Department of Education. NCES. Washington, D.C.: U.S. Government Printing Office.

Derryberry, D., \& Reed, M. (2002). Anxiety-related attentional biases and their regulation by attentional control. Journal of Abnormal Psychology, 111(2), 225-236. https://doi.org/10.1037/0021-843X.111.2.225

DiPerna, J., Volpe, R., \& Elliott, S. (2005). A model of academic enablers and mathematics achievement in the elementary grades. Journal of School Psychology, 43, 379-392. https://doi.org/10.1016/j.jsp.2005.09.002

Dolan, L., Kellam, S., Brown, C., Werthamer-Larson, L., Rebok, G., Mayer, L., ... \& Wheeler, L. (1993). The short-term impact of two classroom-based preventive interventions on aggressive and shy behaviors and poor achievement. Journal of Applied Developmental Psychology, 14, 317-345. https://doi.org/10.1016/0193-3973(93)90013-L

Domitrovich, C., \& Greenberg, M. (2000). The study of implementation: Current findings from effective programs for school-aged children. Journal of Educational and Psychological Consultation, 11, 193-221.

Domitrovich, C., Bradshaw, C., Poduska, J., Hoagwood, K., Buckley, J., Olin, S., ... \& Ialongo, N. (2008). Maximizing the implementation quality of evidence-based preventive interventions in schools: A conceptual framework. Advances in School Mental Health Promotion, 1(3), 6-28. https://doi.org/10.1080/1754730X.2008.9715730

Duncan, G., Dowsett, C., Claessens, A., Magnuson, K., Huston, A., Klebanov, P., ... \& Japel, C. (2007). School readiness and later achievement. Developmental Psychology, 43(6), 1428-1446. https://doi.org/10.1037/0012-1649.43.6.1428

Durlak, J., Weissberg, R., Dymnicki, A., Taylor, R., \& Schellinger, K. (2011). The impact of enhancing students' social and emotional learning: A meta-analysis of school-based universal interventions. Child Development, 82(1), 405-432. https://doi.org/10.1111/j.1467-8624.2010.01564.x

Eaton, W., \& Ennis, L. (1986). Sex differences in motor activity level. Psychological Bulletin, 100, 19-28. https://doi.org/10.1037/0033-2909.100.1.19

Eisenberg, N., Fabes, R., Guthrie, I., \& Reiser, M. (2000). Dispositional emotional and regulation: Their role in predicting quality of social functioning. Journal of Personality and Social Psychology, 78(1), 138-157. https://doi.org/10.1037/0022-3514.78.1.136

Else-Quest, N., Hyde, J., Goldsmith, H., \& Van Hulle, C. (2006). Gender differences in temperament: A meta-analysis. Psychological Bulletin, 132, 33-72. https://doi.org/10.1037/0033-2909.132.1.33

Entwisle, D., Alexander, K., \& Olson, L. (2005). First grade and educational attainment by age 22: A new story. American Journal of Sociology, 110(5), 1458-1502. https://doi.org/10.1086/428444

Evans, G., \& Schamberg, M. (2009). Childhood poverty, chronic stress, and adult working memory. Proceedings of the 
National Academy of Sciences of the United States America, 106(16), 6545-6549. https://doi.org/10.1073/pnas.0811910106

Fergusson, D., \& Horwood, L. (1997). Gender differences in educational achievement in a New Zealand birth cohort. New Zealand Journal of Educational Studies, 32(1), 83-96.

Fixsen, D., \& Blasé, K. (1993). Creating new realities: Program development and dissemination. Journal of Applied Analysis, 26, 597-615. https://doi.org/10.1901/jaba.1993.26-597

Foster, W., \& Miller, M. (2007). Development of the literacy achievement gap: A longitudinal study of kindergarten through third grade. Language, Speech, and Hearing Services in Schools, 38, 173-181. https://doi.org/10.1044/0161-1461(2007/018)

Fuchs, D., Fuchs, L., Al Otaiba, S., Thompson, A., Yen, L., McMaster, K., ... \& Yang, N. (2001). K-PALS: Helping kindergartens with reading readiness: Teachers and researchers in partnerships. Teaching Exceptional Children, 33(4), 76-80. https://doi.org/10.1177/004005990103300411

Furlong, M., McGilloway, S., Bywater, T., Hutchings, J., Smith, S., \& Donnelly, M. (2012). Behavioural and cognitive-behavioural group-based parenting programmes for early-onset conduct problems in children aged 3 to 12 years. Cochrane Database System Review, 15(2), 1-344. https://doi.org/10.4073/csr.2012.12

Garbarino, J., Dubrown, N., Kostelny, K., \& Pardo, C. (1992). Children in danger: Coping with the effects of community violence. San Francisco, CA: Jossey-Bass.

Gartstein, M., Putnam, S., \& Rothbart, M. (2012). Etiology of preschool behavior problems: Contributions of temperament attributes in early childhood. Infant Mental Health, 33(2), 197-211. https://doi.org/10.1002/imhj.21312

Gazelle, H. (2006). Class climate moderates peer relations and emotional adjustment in children with an early history of anxious solitude: A child x environment model. Developmental Psychology, 42, 1179-1192. https://doi.org/10.1037/0012-1649.42.6.1179

Gilliom, M., Shaw, D., Beck, J., Schonberg, M., \& Lukon, J. (2002). Anger regulation in disadvantaged preschool boys: Strategies, antecedents, and the development of self-control. Developmental Psychology, 38, $222-235$. https://doi.org/10.1037/0012-1649.38.2.222

Graziano, P., Reavis, R., Keane, S., \& Calkins, S. (2007). The role of emotion regulation and children's early academic success. Journal of School Psychology, 45(1), 3-19. https://doi.org/10.1016/j.jsp.2006.09.002

Greenberg, L. (1999). Ideal psychotherapy research: A study of significant change process. Journal of Clinical Psychology, 55(12), https://doi.org/10.1002/(SICI)1097-4679(199912)55:12<1467::AID-JCLP5>3.0.CO;2-2

1467-1480.

Greenberg, M., Domitrovich, C., \& Bumbarger, B. (2001). The prevention of mental disorders in school-aged children: Current state of the field. Prevention and Treatment, 4(1), 1-62. https://doi.org/10.1037/1522-3736.4.1.41a

Griffin, E., \& Morrison, F. (1997). The unique contribution of home literacy environment to differences in early literacy skills. Early Child Development and Care, 127(1), 233-243. https://doi.org/10.1080/0300443971270119

Guerin, D. W., Gottfried, A. W., Oliver, P. H., \& Thomas, C. W. (2003). Temperament: Infancy through Adolescence. New York: Kluwer Academic/Plenum Publishers. https://doi.org/10.1007/978-1-4615-0175-6

Hair, N., Hanson, J., Wolfe, B., \& Pollak, S. (2015). Association of child poverty, brain development, and academic achievement. JAMA Pediatrics, E1-E8. https://doi.org/10.1001/jamapediatrics.2015.1475

Hamre, B., \& Pianta, R. (2001). Early teacher/child relationships and the trajectory of children's school outcomes through eighth grade. Child Development, 72, 625-638. https://doi.org/10.1111/1467-8624.00301

Hart, B., \& Risley, T. (1995) Meaningful differences in the everyday experience of young American children. Baltimore, MD: Brookes Publishing.

Hart, D., Hofmann, V., Edelstein, W., \& Keller, M. (1997). The relation of Childhood personality types to adolescent behavior and development: A longitudinal study of Icelandic children. Developmental Psychology, 33(2), $195-205$. https://doi.org/10.1037/0012-1649.33.2.195

Hockenberger, E., Goldstein, H., \& Haas, L. (1999). Effects of commenting during joint book reading by mothers with low SES. Topics in Early Childhood Special Education, 19, 15-27. https://doi.org/10.1177/027112149901900102

Honomichl, R., \& Donnellan, M. (2012). Dimensions of temperament in preschoolers predict risk taking and externalizing behaviors in adolescents. Social Psychology and Personality, 3(1), 14-22. 
https://doi.org/10.1177/1948550611407344

Ialongo, N., Werthamer, L., Kellam, S., Brown, C., Wang, S., \& Lin, Y. (1999). Proximal impact of two first-grade preventive interventions on the early risk behaviors for later substance abuse, depression, and antisocial behavior. American Journal of Community Psychology, 27(5), 599-640. https://doi.org/10.1023/A:1022137920532

Izard, C. (1991). The psychology of emotions. New York: Plenum Press. https://doi.org/10.1007/978-1-4899-0615-1

Janson, H., \& Mathiesen, K. (2008). Temperament profiles from infancy to middle childhood: Development and associations with behavior problems. Developmental Psychology, 44(5), 1314-1328. https://doi.org/10.1037/a0012713

Jennings, P., \& Greenberg, M. (2009). The prosocial classroom: Teacher social and emotional competence in relation to student and classroom outcomes. Review of Education Research, 79(1), 491-525. https://doi.org/10.3102/0034654308325693

Kam, C. M., Greenberg, M., \& Walls, C. (2003). Examining the role of implementation quality in school-based prevention using the PATHS curriculum. Prevention Science, 4(1), 55-63. https://doi.org/10.1023/A:1021786811186

Keenan, K., \& Shaw, D. (1997). Developmental and social influences on young girls' early problem behavior. Psychological Bulletin, 121(1), 95-113. https://doi.org/10.1037/0033-2909.121.1.95

Kellam, S., Rebok, G., Ialongo, N., \& Mayer, L. (1994). The course and malleability of aggressive behavior from early first grade into middle school: Results of a developmental epidemiologically-based prevention trial. Journal of Child Psychology and Psychiatry, 35, 259-281. https://doi.org/10.1111/j.1469-7610.1994.tb01161.x

Kellam, S., Werthamer-Larsson, L., Dolan, L., Brown, C., Mayer, L., Rebok, G., ... \& Wheeler, L. (1991). Developmental epidemiologically based preventive trials: Baseline modeling of early target behaviors and depressive symptoms. American Journal of Community Psychology, 19(4), 563-583. https://doi.org/10.1007/BF00937992

Klassen, R., \& Chiu, M. (2010). Effects on teachers' self-efficacy and job satisfaction: Teacher gender, years of experience, and job stress. Journal of Education Psychology, 102(3), 741-756. https://doi.org/10.1037/a0019237

Kochanska, G., Murray, K., \& Harlan, E. (2000). Effortful control in early childhood: Continuity and change, antecedents, and implications of social development.

Kohen, D., Oliver, L., \& Pierre, F. (2009). Examining the effects of schools and neighbourhoods on the outcomes of kindergarten children in Canada. International Journal of Speech-Language Pathology, 11, 404-418. https://doi.org/10.1080/17549500903085919

Koles, B., O'Connor, E., \& Collins, B. (2013). Associations between child and teacher characteristics and quality of teacher-child relationships: The case of Hungary. European Early Childhood Education Research Journal, 21(1), 53-76. https://doi.org/10.1080/1350293X.2012.760337

Lachance, J., \& Mazzocco, M. (2006). A longitudinal analysis of sex differences in math and spatial skills in primary school age children. Learning and Individual Differences, 16(3), 195-216. https://doi.org/10.1016/j.lindif.2005.12.001

LaFreniere, P., \& Dumas, J. (1996). Social competence and behavior evaluation in children ages 3 to 6 years: The short form (SCBE-30). Psychological Assessment, 8(4), 369-377. https://doi.org/10.1037/1040-3590.8.4.369

Lankford, H., Loeb, S., \& Wyckoff, J. (2002). Teacher sorting and the plight of urban schools: A descriptive analysis. Educational Evaluation and Policy Analysis, 24(1), 37-62. https://doi.org/10.3102/01623737024001037

Lanza, S., Rhoades, B., Nix, R., Greenberg, M., \& Conduct Problems Prevention Research Group. (2010). Modeling the interplay of multilevel risk factors for future academic and behavior problems: A person-centered approach. Developmental Psychopathology, 22(2), 313-335. https://doi.org/10.1017/S0954579410000088

Lawson, K., \& Ruff, H. (2004). Early focused attention predicts outcome for children born prematurely. Journal of Developmental Behavioral Pediatrics, 25(6), 399-406. https://doi.org/10.1097/00004703-200412000-00003

Lee, V., \& Burkam, D. (2002). Inequality at the starting gate: Social Background differences in achievement as children begin school. Washington, D.C.: Economic Policy Institute.

Lengua, L., \& Kovacs, E. (2005). Bidirectional associations between temperament and parenting the prediction of adjustment problems in middle childhood. Journal of Applied Developmental Psychology, 26(1), 21-38. https://doi.org/10.1016/j.appdev.2004.10.001 
Lengua, L., Bush, N., Long, A., Kovacs, E., \& Trancik, A. (2008). Effortful control as a moderator of the relation between contextual risk factors and growth in adjustment problems. Development and Psychopathology, 20, 509-528. https://doi.org/10.1017/S0954579408000254

Li, I., Onaga, E., Shen, P., \& Chiou, H. (2009). Temperament characteristics and science achievement: A longitudinal study of elementary students in Taiwan. International Journal of Science Education, 31, 1175-1185. https://doi.org/10.1080/09500690701793923

Liew, J., Chen, Q., \& Hughes, J. (2010). Child effortful control, teacher-student relationships, and achievement in academically at-risk children: Additive and interactive effects. Early Childhood Research Quarterly, 25(1), 51-64. https://doi.org/10.1016/j.ecresq.2009.07.005

Li-Grining, C. P., Votruba-Drzal, E., Bachman, H. J., \& Chase-Lansdale, P. L. (2006). Are certain preschoolers at risk in the era of welfare reform? The moderating role of children's temperament. Children and Youth Services Review, 28, 1102-1123. https://doi.org/10.1016/j.childyouth.2005.10.016

Lloyd, J., Li, L., \& Hertzman, C. (2009). Early experiences matter: Lasting effect of concentrated disadvantage on children's language and cognitive outcomes. Health and Place, 16(2), 371-380. https://doi.org/10.1016/j.healthplace.2009.11.009

LoCasale-Crouch, J., Mashburn, A., Downer, J., \& Pianta, R. (2008). Pre-kindergarten teachers' use of transition practices and children's adjustment to kindergarten. Early Childhood Research Quarterly, 23(1), 124-139. https://doi.org/10.1016/j.ecresq.2007.06.001

Luthar, S., Cicchetti, D., \& Becker, B. (2000). The construct of resilience: A critical evaluation and guidelines for future work. Child Development, 71(3), 543-562. https://doi.org/10.1111/1467-8624.00164

Maier, M., Vitiello, V., \& Greenfield, D. (2012). A multilevel model of child and classroom level psychosocial factors that support language and literacy resilience of children in Head Start. Early Childhood Research Quarterly, 27(1), 104-114. https://doi.org/10.1016/j.ecresq.2011.06.002

Martin, R. (1989). Activity level, distractibility and persistence: Critical characteristics in early schooling. In G. Kohnstamm, J. Bates, \& M. Rothbart (Eds.), Temperament in childhood (pp. 283-298). Chichester: Wiley.

Martin, R. (1994). Child temperament and common problems in schooling: Hypotheses about causal connections. Journal of School Psychology, 32, 119-134. https://doi.org/10.1016/0022-4405(94)90006-X

Martin, R. P., \& Holbrook, J. (1985). Relationship of temperament characteristics to the academic achievement of first-grade children. Journal of Psychoeducational Assessment, 3, 131-140. https://doi.org/10.1177/073428298500300204

Martin, R., Nagle, R., \& Paget, K. (1983). Relationships between temperament and classroom behavior, teacher attitudes, and academic achievement. Journal of Psychoeducational Assessment, 1(4), 377-386. https://doi.org/10.1177/073428298300100407

Mathewson, K., Jetha, M., Drmic, I., Bryson, S., Goldberg, J., \& Schmidt, L. (2012). Alpha power, coherence, and behavioral symptomatology in autism spectrum disorder. Clinical Neurophysiology, 123(9), 1798-1809. https://doi.org/10.1016/j.clinph.2012.02.061

McClelland, M., Acock, A., \& Morrison, F. (2006). The impact of kindergarten learning-related skills on academic trajectories at the end of elementary school. Early Childhood Research Quarterly, 21(4), 471-490. https://doi.org/10.1016/j.ecresq.2006.09.003

McClowry, S. (1995). The development of the school-age temperament inventory. Merrill-Palmer Quarterly, 41, 271-285.

McClowry, S. (2002a). The temperament profiles of school-aged children. Journal of Pediatric Nursing, 17(1), 3-10. https://doi.org/10.1053/jpdn.2002.30929

McClowry, S. (2002b). Transforming temperament profile statistics into puppets and other visual media. Journal of Pediatric Nursing, 17, 11-17. https://doi.org/10.1053/jpdn.2002.30933

McClowry, S. (2003). Your child's unique temperament: Insights and strategies for responsive parenting. Champaign, IL: Research Press.

McClowry, S., \& Collins, A. (2012). Temperament-based intervention: Reconceptualized from a response-to-intervention framework. In M. Zentner \& R. Shiner (Eds.), Handbook of Temperament (pp. 607-626). New York, NY: The Guilford Press. 
McClowry, S., Giangrande, S., Tommasini, N., Clinton, W., Foreman, N., Lynch, K., \& Ferketich, S. (1994). The effects of child temperament, maternal characteristics, and family circumstances on the maladjustment of school-age children. Research in Nursing and Health, 17(1), 25-35. https://doi.org/10.1002/nur.4770170105

McClowry, S., Rodriguez, E., \& Koslowitz, R. (2008). Temperament-based intervention: Re-examining goodness of fit. European Journal of Developmental Science, 2(1-2), 120-135.

McClowry, S., Rodriguez, E., Tamis-LeMonda, C., Spellman, M., Carlson, A., \& Snow, D. (2013). Teacher/student interactions and classroom behavior: The role of student temperament and gender. Journal of Research in Childhood Education, 27, 283-301. https://doi.org/10.1080/02568543.2013.796330

McClowry, S., Snow, D., Tamis-LeMonda, \& Rodriguez, E. (2010). Testing the efficacy of INSIGHTS on student disruptive behavior, classroom management, and student competence in inner city primary grades. School Mental Health, 2, 25-35. https://doi.org/10.1007/s12310-009-9023-8

McClure, E. (2000). A meta-analytic review of sex differences in facial expression processing and their development in infants, children, and adolescents. Psychological Bulletin, 126(3), 424-453. https://doi.org/10.1037/0033-2909.126.3.424

McCormick, M., O'Connor, E., Cappella, E., \& McClowry, S. (2015). Getting a good start in school: Effects of INSIGHTS on children with high maintenance temperaments. Early Childhood Research Quarterly, 30, 128-139. https://doi.org/10.1016/j.ecresq.2014.10.006

McIntosh, K., Sadler, C., \& Brown, J. (2012). Kindergarten reading skill level and change as risk factors for chronic problem behaviors. Journal of Positive Behavior Interventions, 14(1), 17-28. https://doi.org/10.1177/1098300711403153

McWayne, C., Cheung, K., Wright, L., \& Hahs-Vaugh, D. (2012). Patterns of school readiness among head start children: Meaningful within-group variability during the transition to kindergarten. Journal of Educational Psychology, 104(3), 862-878. https://doi.org/10.1037/a0028884

Melvin, N. (1995). Children's temperament: Intervention for parents. Journal of Pediatric Nursing, 10, 152-159. Mervielde, I., \& De Pauw, S. (2012). Models of child temperament. In M. Zentner \& R. Shiner (Eds.), Handbook of Temperament (pp. 21-40). New York, NY: The Guilford Press. https://doi.org/10.1016/S0882-5963(05)80077-6

Mendez, J., Fantuzzo, J., \& Cicchetti, D. (2002). Profiles of social competence among low-income African American preschooler children. Child Development, 73(4), 1085-1100. https://doi.org/10.1111/1467-8624.00459

Morrow, L., O’Connor, E., \& Smith, J. (1990). Effects of a story reading program on the literacy development of at-risk kindergarten children. Journal of Literacy Research, 22(3), 255-275. https://doi.org/10.1080/10862969009547710

Mullola, S., Jokela, M., Ravaja, N., Lipsanen, J., Hintsanen, M., Alatupa, S., \& Keltikangas-Järvinen, L. (2011). Associations of student temperament and educational competence with academic achievement: The role of teacher age and teacher and student gender. Teaching and Teacher Education, 27, 942-951. https://doi.org/10.1016/j.tate.2011.03.005

Murray, E., \& Harrison, L. (2011). The influence of being ready to learn on children's early school literacy and numeracy achievement. Educational Psychology, 31(5), 529-545. https://doi.org/10.1080/01443410.2011.573771

National Institute of Child Health and Human Development Early Child Care Research Network. (2003). Does amount of time in child care predict socioemotional adjustment during the transition to kindergarten? Child Development, 74, 976-1005. https://doi.org/10.1111/1467-8624.00582

Newman, M., Zuellig, A., Kachin, K., \& Constantino, M. (1998). Examination of the reliability and validity of the PDSR: A self-report measure of panic disorder. Paper presented at the $32^{\text {nd }}$ annual meeting of the Association for Advancement of Behavior Therapy, Washington, D.C.

Noguera, P. (2003a). City schools and the American dream: Reclaiming the promise of public education. New York, NY: Teachers College Press.

Noguera, P. (2003b). The trouble with Black boys: The role and influence of environmental and cultural factors on the academic performance of African American males. Urban Education, 38, 431-459. https://doi.org/10.1177/0042085903038004005

Noguera, P. (2008). The trouble with Black boys:...And other reflections on race, equity, and the future of public education. San Francisco, CA: Jossey-Bass.

O’Connor, E., \& McCartney, K. (2007). Examining teacher-child relationships and achievement as part of an ecological model of development. American Educational Research Journal, 44, 240-269. 
https://doi.org/10.3102/0002831207302172

O'Connor, E., Cappella, E., McCormick, M., \& McClowry, S. (2014). Enhancing the academic development of shy children: A test of the efficacy of INSIGHTS. School Psychology Review, 43(3), 239-259.

O’Connor, E., Rodriguez, E., Cappella, E., Morris, J., \& McClowry, S. (2012). Child disruptive behavior and parenting efficacy: A comparison of the effects of two models of INSIGHTS. Journal of Community Psychology, 40(5), 555-572. https://doi.org/10.1002/jcop.21482

O’Donnell, J., Hawkins, J., Catalano, R., Abbott, R., Day, L. (1995). Preventing school failure, drug use, and delinquency among low-income children: Long-term intervention in elementary schools. American Journal of Orthopsychiatry, 65(1), 87-100. https://doi.org/10.1037/h0079598

Palisin, H. (1986). Preschool temperament and performance on achievement tests. Developmental Psychology, 22(6), 766-770. https://doi.org/10.1037/0012-1649.22.6.766

Pekrun, R., Elliot, A., \& Maier, M. (2009). Achievement goals and achievement emotions: Testing a model of their joint relations with academic performance. Journal of Educational Psychology, 101, 115-135. https://doi.org/10.1037/a0013383

Perbandt, K. (2007). Differential effects of incongruent anger expression on memory performance. Journal of Individual Differences, 28(3), 129-137. https://doi.org/10.1027/1614-0001.28.3.129

Pianta, R., \& Cox, M. (Ed) The transition to kindergarten. A series from the National Center for Early Development and Learning. Chapel Hill, NC: National Center for Early Development and Learning.

Pianta, R., \& Walsh, D (1996). High-risk children in schools: Constructing sustaining relationships. New York: Routledge.

Pianta, R., Cox, M., Early, D., Rimm-Kaufman, S., Laparo, K., \& Taylor, L. (1998). A national perspective of entry to school: The NCEDLS's Transition Practices Survey. Symposium presentation at the annual meeting of the American Educational Research Association, San Diego.

Pianta, R., La Paro, K., Payne, C., Cox, M., \& Bradley, R. (2002). The relation of kindergarten classroom environment to teacher, family, and school characteristics and child outcomes. The Elementary School Journal, 102(3), 225-238. https://doi.org/10.1086/499701

Portilla, X., Ballard, P., Adler, N., Boyce, W., \& Obradović, J. (2014). An integrative view of school functioning: Transactions between self-regulation, school engagement, and teacher-child relationship quality. Child Development, 85(5), 1915-1931. https://doi.org/10.1111/cdev.12259

Posner, M., \& Rothbart, M. (2005). Influencing brain networks: Implications for education. TRENDS in Cognitive Science, 9(3), 99-103. https://doi.org/10.1016/j.tics.2005.01.007

Prior, M., Sanson, A., Smart, D., \& Oberklaid, F. (2000). Pathways from infancy to adolescence: Australian Temperament Project 1983-2000. Melbourne, Australia: Australian Institute of Family Studies.

Quirk, M., Nylund-Gibson, K., \& Furlong, M. (2013). Exploring patterns of Latino/a children's school readiness at kindergarten entry and their relations with grade 2 achievement. Early Childhood Research Quarterly, 28(2), 437-449. https://doi.org/10.1016/j.ecresq.2012.11.002

Ramey, C., \& Ramey, S. (1999). Beginning school for children at risk. In R. Pianta \& M. Cox (Eds.), The transition to kindergarten. A series from the National Center for Early Development and Learning (pp. 217-251). Chapel Hill, NC: National Center for Early Development and Learning.

Ramey, C., Campbell, F., Burchinal, M., Skinner, M., Gardner, D., \& Ramey, S. (2000). Persistent effects of early childhood education on high-risk children and their mothers. Applied Developmental Science, 4(1), 2-14. https://doi.org/10.1207/S1532480XADS0401_1

Rapee, R. (2013). The preventative effects of a brief, early intervention for preschool-aged children at risk for internalising: Follow-up into middle adolescence. Journal of Child Psychology and Psychiatry, 54(7), 780-788. https://doi.org/10.1111/jcpp.12048

Rapee, R., Kennedy, S., Ingram, M., Edwards, S., \& Sweeney, L. (2005). Prevention and early intervention of anxiety disorders in inhibited preschool children. Journal of Consulting and Clinical Psychology, 73(3), 488-497. https://doi.org/10.1037/0022-006X.73.3.488

Raver, C. C., Jones, S. M., Li-Grining, C. P., Zhai, F., Metzger, M. W., \& Solomon, B. (2009). Targeting children's behavior problems in preschool classrooms: A cluster- randomized controlled trial. Journal of Consulting and 
Clinical Psychology, 77, 302-316. https://doi.org/10.1037/a0015302

Ready, D., LoGerfo, L., Burkam, D., \& Lee, V. (2005). Explaining girls' advantage in kindergarten literacy learning: Do classroom behaviors make a difference? The Elementary School Journal, 106(1), 21-38. https://doi.org/10.1086/496905

Rettew, D. (2008). Temperament and child psychopathology: Beyond associations. In J. Hudziak (Ed), Developmental and Psychopathological Wellness: Genetic and Environmental Influences (pp. 67-84). Washington, DC: American Psychiatric Publishing, Inc.

Reynolds, A., Temple, J., Robertson, D., \& Mann, E. (2001). Long-term effects of an early childhood intervention on educational achievement and juvenile arrest: A 15-year follow-up of low-income children in public schools. The Journal of the American Medical Association, 285(18), 2339-2346. https://doi.org/10.1001/jama.285.18.2339

Rimm-Kaufman, S., \& Pianta, R. (2000). An ecological perspective on the transition to kindergarten: A theoretical framework to guide empirical research. Journal of Applied Developmental Psychology, 21(5), 491-511. https://doi.org/10.1016/S0193-3973(00)00051-4

Rimm-Kaufman, S., Curby, T., Grimm, K., Nathanson, L., \& Brock, L. (2009). The contribution of children's self-regulation and classroom quality to children's adaptive behaviors in the kindergarten classroom. Developmental Psychology, 45(4), 958-972. https://doi.org/10.1037/a0015861

Rimm-Kaufman, S., Pianta, R., \& Cox, M. (2000). Teachers' judgments of problems in the transition to kindergarten. Early Childhood Research Quarterly, 15, 147-166. https://doi.org/10.1016/S0885-2006(00)00049-1

Robins, R., John, O., \& Caspi, A. (1998). The typological approach to studying personality. In R.B. Cairns, L.R. Bergman, \& J. Kagan (Eds.), Methods and models for studying the individual, pp. 135-160. Thousand Oaks, CA, Sage.

Robins, R., John, O., Caspi, A., Moffitt, T., \& Stouthamer-Loeber, M. (1996). Resilient, overcontrolled, and under controlled boys: Three replicable personality types. Journal of Personality and Social Psychology, 70, 157-171. https://doi.org/10.1037/0022-3514.70.1.157

Romano, E., Babchishin, L., Pagani, L., \& Kohen, D. (2010). School readiness and later achievement: Replication and extension using a nationwide Canadian survey. Developmental Psychology, 46(5), 995-1007. https://doi.org/10.1037/a0018880

Roorda, D., Koomen, H., Spilt, J., \& Oort, F. (2011). The influence of affective teacher-student relationships on students' school engagement and achievement: A meta-analytic approach. Review of Educational Research, 81(4), 493-529. https://doi.org/10.3102/0034654311421793

Roorda, D., Koomen, H., Thijs, J., \& Oort, F. (2013). Changing interactions between teachers and socially inhibited kindergarten children: An interpersonal approach. Journal of Applied Developmental Psychology, 34(4), 173-184. https://doi.org/10.1016/j.appdev.2013.03.002

Rothbart, M. K., \& Bates, J. E. (1998). Temperament in W. Damon (Ed.), Handbook of Child Psychology, Vol. 3 (5 ${ }^{\text {th }}$ ed., pp. 105-176). New York: Wiley.

Rothbart, M., \& Jones, L. (1998). Temperament, self-regulation, and education. The School Psychology Review, 27, 479-491.

Rothbart, M., Ahadi, S., \& Evans, D. (2000). Temperament and personality: Origins and outcomes. Journal of Personality and Social Psychology, 78(1), 122-135. https://doi.org/10.1037/0022-3514.78.1.122

Rothbart, M., Derryberry, D., \& Hershey, K. (2000). Stability of temperament in childhood: Laboratory infant assessment to parent report at seven years. In V. Molfese \& D. Molfese (Eds.), Temperament and personality across the life space (pp. 85-119). Hillsdale, NJ: Erlbaum.

Rudasill, K., \& Rimm-Kauffman, S. (2009). Teacher/child relationship quality: The roles of child temperament and teacher/child interactions. Early Childhood Research Quarterly, 24, 107-120. https://doi.org/10.1016/j.ecresq.2008.12.003

Rudasill, K., Gallagher, K., \& White, J. (2010). Temperament attention and activity, classroom emotional support, and academic achievement in third grade. Journal of School Psychology, 48, 113-134. https://doi.org/10.1016/j.jsp.2009.11.002

Rydell, A. M., Bohlin, G., \& Thorell, L. (2005). Representations of attachment to parents and shyness as predicators of children's relationships with teachers and peer competence in preschool. Attachment and Human Development, 7, 197-204. https://doi.org/10.1080/14616730500134282 
Sameroff, A., \& Haith, M. (1996). The five to seven year shift: The age of reason and responsibility (The John D. and Catherine T. MacArthur Foundation series on mental health and development). Chicago, IL: The University of Chicago Press.

Schaughency, E., \& Fagot, B. (1993). The prediction of adjustment at age 7 from activity at age 5. Journal of Abnormal Child Psychology, 21, 29-50. https://doi.org/10.1007/BF00910487

Schoen, M., \& Nagle, R. (1994). Prediction of school readiness from kindergarten temperament scores. Journal of School Psychology, 32(2), 135-147. https://doi.org/10.1016/0022-4405(94)90007-8

Schultz, K., Clerkin, S., Halperin, J., Newcorn, J., Tang, C., \& Fan, J. (2009). Dissociable neural effects of stimulus valence and preceding context during the inhibition of responses to emotional faces. Brain. Mapp., 30, 2821-2833. https://doi.org/10.1002/hbm.20706

Schweinhart, L., \& Weikart, D. (1997). High/Scope Preschool Curriculum comparison study through age 23. Early Childhood Research Quarterly, 12, 117-143. https://doi.org/10.1016/S0885-2006(97)90009-0

Sharkey, P. (2009). Neighborhoods and the Black-White mobility gap. Washington, D.C.: The Economic Mobility Project: An Initiative of the Pew Charitable Trusts.

Sheeber, L., \& Johnson, J. (1994). Evaluation of a temperament-focused, parent-training program. Journal of Clinical Psychology, 23, 249-259. https://doi.org/10.1207/s15374424jccp2303_3

Shonkoff, J., \& Phillips, D. (Eds.). (2000). From neurons to neighborhoods: The science of early childhood development. Washington, DCL National Academy Press.

Silver, M., Ress, D., \& Heeger, D. (2005). Topographic maps of visual spatial attention in human parietal cortext. Journal of Neurophysiology, 94, 1358-1371. https://doi.org/10.1152/jn.01316.2004

Skinner, E., Zimmer-Gembeck, M., \& Connell, J. (1998). Individual differences and the development of perceived control. Monographs of the Society of Research in Child Development, 254(63), 2-3. https://doi.org/10.2307/1166220

Social and Character Development Research Consortium. (2010). Efficacy of schoolwide programs to promote social and character development and reduce problem behavior in elementary school children (NCER 2011-2001). Washington, DC: National Center for Education Research, Institute of Education Sciences, U.S. Department of Education.

Stright, A., Gallagher, K., \& Kelly, K. (2008). Infant temperament moderates relations between maternal parenting in early childhood and children's adjustment in first grade. Child Development, 79, 186-200. https://doi.org/10.1111/j.1467-8624.2007.01119.x

Taylor, C., Liang, B., Tracy, A., Williams, L., \& Seigle, P. (2002). Gender differences in middle school adjustment, physical fighting, and social skills: Evaluation of a social competency program. Journal of Primary Prevention, 23(2), 259-272. https://doi.org/10.1023/A:1019976617776

Teerikangas, O., Aronen, E., Martin, R., \& Huttunen, M. (1998). Infant temperament and early intervention on the psychiatric symptoms of adolescents. Journal of the American Academy of Child and Adolescent Psychiatry, 37(10), 1070-1076. https://doi.org/10.1097/00004583-199810000-00017

Thomas, A., \& Chess, S. (1977). Temperament and development. New York, Brunner/Mazel. Thomas, A., \& Chess, S. (1984), Genesis and evolution of behavioral disorders: from infancy to early adult life. American Journal of Psychiatry, 141, 1-9.

Thomas, A., Chess, S., \& Birch, H. (1968). Temperament and behavior disorders in children. New York, NY: New York University Press.

Trentacosta, C., \& Izard, C. (2007). Kindergarten children's emotion competence as a predicator of their academic competence in first grade. Emotion, 7, 77-88. https://doi.org/10.1037/1528-3542.7.1.77

Valiente, C., Lemery-Chalfant, K., \& Swanson, J. (2010). Prediction of kindergarteners' academic achievement from their effortful control and emotionality: Evidence for direct and moderated relations. Journal of Educational Psychology, 102(3), 550-560. https://doi.org/10.1037/a0018992

Valiente, C., Lemery-Chalfant, K., Swanson, J., \& Reiser, M. (2008). Prediction of children's academic competence from their effortful control, relationships, and classroom participation. Journal of Educational Psychology, 100, 67-77. https://doi.org/10.1037/0022-0663.100.1.67

Veenstra, R., Lindenberg, S., Oldehinkel, A., De Winter, A., \& Ormel, J. (2006). Temperament, environment, and 
antisocial behavior in a population sample of preadolescent boys and girls. International Journal of Behavioral Development, 30(5), 422-432. https://doi.org/10.1177/0165025406071490

Velting, O., \& Whitehurst, G. (1997). Inattention-hyperactivity and reading achievement in children from low-income families: A longitudinal model. Journal of Abnormal Child Psychology, 25, 321-331. https://doi.org/10.1023/A:1025716520345

Vilijaranta, J., Aunola, K., Mullola, S., Virkkala, J., Hirvonen, R., \& Nurmi, J. E. (2015). Children's temperament and academic skill development during first grade: Teachers' interaction styles as mediators. Child Development, 86(4), 1191-1209. https://doi.org/10.1111/cdev.12379

Wagner, M., \& Blackorby, J. (1996). Transition from high school to work or college: How special education students fare. School readiness: closing racial and ethnic gaps. The Future of Children, 6(1), 103-120. https://doi.org/10.2307/1602496

Walker, O., \& Henderson, H. (2012). Temperament and social problem solving competence in preschool: Influences on academic skills in early elementary school. Social Development, 21(4), 761-779. https://doi.org/10.1111/j.1467-9507.2011.00653.x

Wang, M., Haertel, G., \& Walberg, H. (1997). Learning influences. In H. J. Walberg \& G. D. Haertel (Eds.), Psychology and educational practice (pp. 199-211). Berkeley, CA: McCatchan.

Webster-Stratton, C., \& Taylor, T. (2001). Nipping early risk factors in the bud: Preventing substance abuse, delinquency, and violence in adolescence through interventions targeted at young children (0-8 years). Prevention Science, 2(3), 165-192. https://doi.org/10.1023/A:1011510923900

Webster-Stratton, C., Reid, M., \& Hammond, M. (2001). Treating children with early-onset conduct problems: Intervention outcomes for parent, child and teacher training. Journal of Clinical Child and Adolescent Psychology, 42, 943-952

Wendling, B., Schrank, F., \& Schmitt, A. (2007). Woodcock-Johnson III Assessment service bulletin number 8: Educational interventions related to the Woodcock-Johnson III Tests of Achievement. Rolling Meadows, IL: Riverside Publishing.

Wills, T., McNamara, G., Vaccaro, D., \& Hirky, A. (1996). Escalated substance use: A longitudinal grouping analysis from early to middle adolescence. Journal of Abnormal Psychology, 105, 166-180. https://doi.org/10.1037/0021-843X.105.2.166

Wood, D., Kaplan, R., \& McLoyd, V. (2007). Gender differences in the educational expectations of urban, low-income African American youth: The role of parents and the school. Journal of Youth and Adolescence, 36, 417-427. https://doi.org/10.1007/s10964-007-9186-2

Zalewski, M., Lengua, L., Wilson, A., Trancik, A., \& Bazinet, A. (2011). Emotion regulation profiles, temperament, and adjustment problems in preadolescents. Child Development, 82(3), 951-966. https://doi.org/10.1111/j.1467-8624.2011.01575.x

Zentner, M., \& Bates, J. (2008). Child temperament: An integrative review of concepts, research programs, and measures. European Journal of Developmental Science, 2(1/2), 7-37.

Zentner. M., \& Shiner, R. (2012). Fifty years of progress in temperament: A synthesis of major themes, findings, and challenges and a look forward. In M. Zentner \& R. Shiner (Eds.), Handbook of Temperament (pp. 673-700). New York, NY: The Guilford Press.

Zentner. M., \& Shiner, R. (2012). Handbook of Temperament. New York, NY: The Guilford Press.

Zill, N. (1999). Setting an example: The health, medical care, and health-related behavior of American parents. Washington, DC: Child Trends.

Zins, J., Weissberg, R., Wang, M., \& Walberg, H. (Eds.). (2004). Building academic success through social and emotional learning: What does the research say? New York: Teachers College Press.

\section{Copyrights}

Copyright for this article is retained by the author(s), with first publication rights granted to the journal.

This is an open-access article distributed under the terms and conditions of the Creative Commons Attribution license which permits unrestricted use, distribution, and reproduction in any medium, provided the original work is properly cited. 